\title{
The Effect of Taxpayer Compliance and Awareness Towards Local Own-Source Revenue with Tax Sanctions as Intervening Variables
}

\author{
Ati Retna Sari*, Rima Dini Alfa Rizki \\ Accounting Study Program, Faculty of Economics \& Business \\ Universitas PGRI Kanjuruhan Malang \\ Malang, Indonesia \\ *atiretnasari@unikama.ac.id
}

\begin{abstract}
This study aims to examine the effect of taxpayer compliance and taxpayer awareness partially on tax penalties. This study also examines taxpayer compliance, taxpayer awareness and partial tax sanctions on local own-source revenue. The population were the individual taxpayers in the Regional Tax Service Agency of Malang City. The sampling technique used incidental sampling method; the researcher took the sample from the taxpayers who visited the office during the research. The data used are primary data in the form of answers from respondents through questionnaires. The data were analyzed using path analysis which was previously tested using classical assumptions. Meanwhile the hypothesis were tested using the $t$ test (partial). The results of this study indicate that taxpayer compliance and taxpayer awareness have no effect on tax sanctions. Taxpayer compliance has no effect on the Local OwnSource Revenue. Taxpayer awareness affects tax sanctions. Meanwhile, tax sanctions have no effect on Local Own-Source Revenue. The findings also indicate that tax sanctions as an intervening variable of the compliance and the awareness of taxpayers have no effect to the Local Own-Source Revenue.
\end{abstract}

Keywords-taxpayer compliance, taxpayer awareness, local revenue, tax sanctions

\section{INTRODUCTION}

Taxes are a source of state revenue besides oil and gas. Taxes have an important role for national development aimed at increasing the prosperity and welfare of society. This means that the tax system must continue to be refined, tax collection intensified, and the taxation apparatus / management must also improve so that it can play a big role in national development. Taxpayer compliance can be defined as an attitude or behavior of a taxpayer who carries out all his tax obligations and enjoys all tax rights in accordance with the provisions of the applicable laws and regulations [1]. In addition, awareness of the importance of taxes from the public indirectly contributes to national development. Ease of payment and awareness of taxes from the public must be owned so that it can create good national development.
Since January 1, 2001, the Government of Malang City has anticipated one of the agencies handling Regional Revenue by establishing a Regional Revenue Service based on Regional Regulation Number 9 of 2000 concerning the formation, position, main duties and organizational structure of the service as an implementing element of the Regional Government and its main duties and functions, elaborated in the Decree of the Mayor of Malang Number 10 of 2001 concerning Description, Duties, Functions, and Work Procedures of Malang City Revenue Service. The Malang City Regional Tax Service Agency has efforts to increase tax payments in order to meet local tax targets. Considering that there are still many data that are not detailed, such as double SPPT and not yet segregated between vacant land objects and empty buildings, and the database has not been properly integrated. This can be seen in the image in Figure 1:

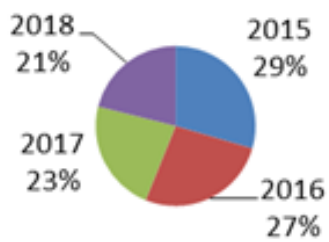

Fig. 1. Realization of land and building tax revenue during 2015-2018 (Source: Malang Regional Tax Service Agency).

As we can see in Figure 1, the realization of land and building tax in Malang City from the last 4 years has still decreased. When viewed from its development, urbanization continues and the need for housing increases beyond the capacity of the government. The land and building tax revenue should also increase. But in reality, it is not easy to make taxpayers aware and obedient to pay their taxes. Many taxpayers do not carry out their obligations even though they already have an NPWPD. Ownership of NPWPD should be able to provide benefits that are in line with the interests of the taxpayer.

Taxpayer compliance can be defined as an attitude or behavior of a taxpayer who carries out all his tax obligations 
and enjoys all tax rights in accordance with the provisions of the applicable laws and regulations [1]. In addition, awareness of the importance of taxes from the community indirectly plays an important role in the smooth running of national development.

One of the ways the Government overcomes tax violations is by issuing a Taxation Law. In this law, there are provisions regarding tax sanctions aimed at taxpayers who do not comply and violate taxation rules. With the existence of tax sanctions, it is hoped that it can deter them or fear these sanctions.

\section{METHODS}

The data is obtained from the results of respondents' answers through distributing questionnaires at the Regional Tax Service Agency of Malang City. The research population is individual taxpayers in the Regional Tax Service Agency of Malang City. The sampling technique uses incidental sampling, namely the sampling technique based on chance, whoever is accidentally encountered while visiting or coming to the Malang City Tax Service Agency. So that the number of samples obtained in this study were 38 respondents. The analysis technique used in this research is path analysis. The model is shown in Eq. 1-2:

$$
\begin{gathered}
Z=P Z X 1+\rho Z X 2+\varepsilon 1 \\
Y=P Y X 1+\rho Y X 2+P Z Y+\varepsilon 2
\end{gathered}
$$

$$
\begin{aligned}
& \text { Notes: } \\
& \mathrm{Y}=\text { Original Local Income } \\
& \mathrm{P}=\text { Regression coefficient } \\
& \mathrm{X} 1 \text { = Taxpayer Compliance } \\
& \mathrm{X} 2=\text { Taxpayer Awareness } \\
& \mathrm{Z} \text { = local revenue } \\
& \varepsilon 1,2=\text { Residual }
\end{aligned}
$$

\section{FINDINGS AND DISCUSSION}

From the hypothesis testing results, it is found that the value of sig. Path X1 ==> Y (P1) of 0.950 is greater than alpha 0.05 , this indicates that taxpayer compliance has no effect on Regional Original Income. Thus, the first hypothesis which states that taxpayer compliance has an effect on Regional Original Income is rejected.

Next, the value of sig. Path $\mathrm{X} 2==>\mathrm{Y}(\mathrm{P} 2)$ of 0.280 , greater than alpha 0.05 , this indicates that taxpayer compliance has no effect on Regional Original Income. Thus, the second hypothesis which states that taxpayer awareness has an effect on Regional Original Income is rejected.

Furthermore, the value of sig. Path X1 ==> Z (P3) of 0.111 is greater than alpha 0.05 , this indicates that taxpayer compliance has no effect on tax sanctions. Thus, the third hypothesis which states that taxpayer compliance has an effect on Tax Sanctions is rejected.

The sig value. Path $\mathrm{X} 2==>\mathrm{Z}(\mathrm{P} 4)$ of 0.019 is greater than alpha 0.05 , this indicates that taxpayer awareness affects tax sanctions. Thus, the fourth hypothesis which states that taxpayer awareness has an effect on Tax Sanctions is accepted.

It is also found that the value of sig. Path $\mathrm{Z}==>\mathrm{Y}(\mathrm{P} 5)$ of 0.150 is greater than alpha 0.05 , this indicates that tax sanctions have no effect on tax sanctions. Thus, the fifth hypothesis which states that tax sanctions have no effect on Regional Original Income is accepted.

The sig value. Path $\mathrm{X} 1==>\mathrm{Z}(\mathrm{P} 3)$ of 0.111 is greater than alpha 0.05 , this indicates that taxpayer compliance has no effect on tax sanctions. Meanwhile, the sig. path $\mathrm{Z}==>\mathrm{Y}(\mathrm{P} 5)$ is 0.150 greater than alpha 0.05 . This indicates that tax sanctions have no effect on Regional Original Income. Thus, the sixth hypothesis which states that tax sanctions as an intervening variable between taxpayer compliance with Regional Original Income have no effect is accepted.

Lastly, the value of sig. Path X2 ==> Z (P4) of 0.019 is smaller than alpha 0.05 , this indicates that taxpayer awareness affects tax sanctions. Meanwhile, the sig. path $\mathrm{Z}==>\mathrm{Y}(\mathrm{P5})$ is 0.150 greater than alpha. This indicates that tax sanctions have no effect on Regional Original Income. Thus, the seventh hypothesis which states that tax sanctions as an intervening variable between taxpayer awareness of Regional Original Income have no effect is accepted.

The path coefficient of the taxpayer compliance variable which is positive with a significance value that shows that taxpayer compliance has no effect on Regional Original Income. The results of this study support the research conducted by Olivia Jessica Yusuf Kastolani and Moh. Didik Ardiyanto [2] which proves that the level of taxpayer compliance has no effect on income tax revenue. Taxpayer compliance is not the only benchmark for increasing the income of a region. This is because the level of compliance of taxpayers in carrying out their tax obligations is still said to be volatile. This can happen because sometimes taxpayers deliberately avoid their tax obligations and neglect their taxes. This illustrates that the level of taxpayer compliance does not have an impact on income tax revenue.

The path coefficient of the taxpayer awareness variable has a positive sign with a significance value which shows that taxpayer awareness has no effect on Regional Original Income. The results of this study support the research conducted by Marisa Herryanto and Agus Arianto Toly [3] proving that taxpayer awareness has no effect on income tax revenue. Taxpayer awareness is formed by the dimensions of taxpayer perceptions, taxpayer knowledge, taxpayer characteristics and tax education. Taxpayer awareness will increase when a positive perception appears in society [4]. What is meant by positive perception of taxes does not only mean being aware of paying taxes, but also having to really understand and understand taxation. This is what makes the tax can be implemented properly so that the community will pay the tax voluntarily without any coercion from any party. So if the taxpayer's awareness has a positive effect on tax payments, it will indirectly increase the value of Regional Original Income and vice versa. 
The variable path coefficient of taxpayer compliance has a positive sign with a significance value which indicates that the taxpayer compliance variable has no effect on tax penalties. The results of this study are in accordance with Arinta Wulansari [5], which states that tax compliance can be defined as a condition in which the taxpayer fulfills all obligations and exercises his taxation rights. This means that taxpayers should have the willingness to fulfill their tax obligations in accordance with applicable regulations without the need for audits, warnings or threats to exist or not.

The path coefficient of the taxpayer awareness variable has a positive sign with a significance value which indicates that taxpayer awareness has an effect on tax sanctions. The results of this study are in accordance with I Gede Prayuda Budhiartama I and Ketut Jati [6] who state that taxpayer awareness is a constellation of cognitive, affective, conative components that interact in understanding, feeling, and behaving towards the meaning and function of taxes. The higher the level of taxpayer awareness that is owned, it can minimize violations that might occur if the taxpayer does not carry out their obligations.

The variable path coefficient of tax sanctions has a positive sign with a significance value which indicates that the tax sanction variable has no effect on Regional Original Income. The results of this study support the research conducted by Ira Destinna Pertiwi [7] proving that the application of tax sanctions has no effect on Regional Original Income. Tax sanction is an action in the form of punishment given to people who violate the rules. The existence of this tax sanction aims to provide a deterrent effect for taxpayers who still violate it. However, although tax sanctions are clearly regulated in the taxation law, in fact there are still taxpayers who violate and do not comply with their tax obligations. From this explanation it can be concluded that tax sanctions have no effect on Regional Original Income.

Tax sanction is an action in the form of punishment given to people who violate the rules. Therefore, it is very important for taxpayers to understand tax sanctions in order to know the legal consequences that were carried out or not carried out. That way it will reduce unwanted violations. The existence of this tax sanction is intended to provide a deterrent effect by the imposition of fines for taxpayers who postpone payment, so the taxpayer will not receive sanctions.

According to I Gede Prayuda Budhiartama I and Ketut Jati [6] which states that taxpayer awareness is a constellation of cognitive, affective, conative components, which interact in understanding, feeling, and behaving towards the meaning and function of taxes. The higher the level of taxpayer awareness that is owned, it can minimize violations that might occur if the taxpayer does not carry out their obligations.

Based on the results of the previous research and discussion, it is suggested that the Regional Tax Service Institution should continue to improve the quality of tax services, both in terms of improving the quality of human resources and other facilities, and to impose firmer sanctions for taxpayers who are still not compliant with paying their taxes.

\section{CONCLUSION}

It can be concluded that the taxpayer compliance variable does not directly affect the Regional Original Income at the Malang City Regional Tax Service Agency. So that the first hypothesis in this study is rejected. Taxpayer awareness variable does not directly affect the Malang City Local Tax Service. So that the second hypothesis in this study is rejected.

Then the taxpayer compliance variable does not directly affect the tax sanctions on the Regional Tax Service Agency of Malang City. So that the third hypothesis in this study is rejected. Taxpayer awareness directly affects the Regional Original Income at the Malang City Regional Tax Service Agency. So that the fourth hypothesis in this study is accepted and tax sanctions do not directly affect the Regional Original Income at the Regional Tax Service Agency of Malang City. So that the fifth hypothesis in this study is accepted.

Tax sanctions as an intervening variable between taxpayer compliance with Regional Original Income have no effect on the Malang City Regional Tax Service Agency. So that the sixth hypothesis in this study is accepted. Tax sanctions as an intervening variable between taxpayer awareness of Regional Original Income have no effect on the Malang City Regional Tax Service Agency. So that the seventh hypothesis in this study is accepted.

\section{REFERENCES}

[1] Safri Nurmantu, Pengantar Perpajakan. Yayasan Obor Indonesia, 2009.

[2] O.J.Y. Kastolani and M. D. Ardiyanto, "Pengaruh Tingkat Kepatuhan Wajib Pajak dan Pemeriksaan terhadap Penerimaan Pajak Penghasilan," Diponegoro J. Account., vol. 6, no. 3, pp. 669-679, 2017.

[3] M. Herryanto and A. A. Toly, "Pengaruh kesadaran wajib pajak, kegiatan sosialisasi perpajakan, dan pemeriksaan pajak terhadap penerimaan pajak penghasilan di KPP Pratama Surabaya Sawahan,” Tax Account. Rev., vol. 1, no. 1, p. 124, 2013.

[4] M.H.K.K. Suryadi, "Pelayanan, Kepatuhan Wajib Pajak dan Pengaruhnya Terhadap Kinerja Penerimaan Pajak; Suatu Survei di Wilayah Jawa Timur,”J. Keuang. Publik, vol. 4, no. 1, 2006.

[5] A. Wulansari, "Pengaruh Penerapan Sanksi Perpajakan, Kesadaran dan Kepatuhan Wajib Pajak Terhadap Ketepatan Pelaporan SPT Wajib Pajak Oranf Pribadi," J. Ris. Mhs. Account., 2015.

[6] I.G.P. Budhiartama and I.K. Jati, "Pengaruh sikap, kesadaran wajib pajak dan pengetahuan perpajakan pada kepatuhan membayar pajak bumi dan bangunan,” E-Jurnal Akunt., vol. 15, no. 2, pp. 1510-1535, 2016.

[7] I.D. Pertiwi, "Pengaruh Penerapan Sanksi Pajak Reklame Terhadap Pendapatan Asli Daerah di Kota Bandung (Studi Empiris Pada Dinas Pendapatan Asli Daerah Kota Bandung).” Universitas Widyatama, 2015. 